\title{
Total CK activity and isoenzyme patterns in normal and neoplastic tissue of gastrointestinal tract
}

\author{
SWEI H TSUNG \\ From the Department of Pathology, Methodist Hospital of Gary Inc, 600 Grant Street, \\ Gary, Indiana 46402, USA
}

SUMMARY Total creatine kinase (CK) activity and isoenzyme distribution were determined in normal and tumour tissue of gastrointestinal (GI) tract. Total CK activity per gram wet tissue appeared to be markedly reduced in malignant tumour tissue, yet it was raised in benign tumour tissue. CK-BB was the predominant isoenzyme in both normal and tumour tissue of GI tract. Alteration of isoenzyme pattern was noted between the normal and tumour tissue. In one patient, macro-CK was found in tissue homogenate.

Two studies ${ }^{1}{ }^{2}$ have demonstrated the pattern of creatine kinase (CK, EC 2.7.3.2.) isoenzymes in normal gastrointestinal (GI) tissue. However, the pattern observed in neoplasms of GI tissue has not been described. This study examines CK isoenzymes in normal, benign, and malignant tumour tissue of the GI tract.

\section{Material and methods}

Seven men and three women (50-78 y, median age 65$)$ undergoing GI resection for benign and malignant tumours were studied; nine patients underwent colectomy and one patient subtotal gastrectomy. Blood was sampled from each patient within $24 \mathrm{~h}$ before surgery. The surgical specimens were sent to the laboratory immediately after their removal. Portions of tumour tissue and normal tissue away from the tumour were obtained for CK assays. The remaining specimens were fixed in formalin for histological examination.

Tissue homogenates were prepared as described in a previous report. ${ }^{3}$ CK activity was estimated at $37^{\circ} \mathrm{C}$ with an HMA analyser (Hycel Inc, Houston, TX 77036) by the kinetic method of Rosalki ${ }^{4}$ with reagents from Roche Diagnostics, Division of Hoffmann-La Roche, Inc, (Nutley, NJ 07110).

Total serum CK activity and CK isoenzymes were determined the same day received or within one week after storage at $-20^{\circ} \mathrm{C}$. Tissue was homogenised either the same day or within one week stored at $-20^{\circ} \mathrm{C}$. Total CK activity and CK isoenzymes were determined the same day as the tissue homogenates were prepared.

The serum and supernatant fluid of tissue homogenates were chromatographed by discontinuousgradient elution from diethylaminoethyl SephadexA50 (Pharmacia Lab Inc, Piscatway, NJ 08854), as described by Yasmineh and Hanson. ${ }^{5}$ The serum and supernatant fluid of tissue homogenates were also electrophoresed at pH 8.8 on cellulose acetate film by the CK isoenzyme procedure of Helena Laboratories, Beaumont, TX 77704).

\section{Results}

Total serum CK activity of the 10 patients was all within normal limits, ranging from 35 to $58 \mathrm{U} / 1$ (normal range: 24-60 U/l). None of these patients had circulating CK-MB or CK-BB by both column and electrophoretic methods.

The Table summarises the results of CK activities and proportion of CK isoenzyme in the normal GI tissue or benign and malignant tumour tissue. The CK activity of normal GI tissue ranged from 111 to $258 \mathrm{U} / \mathrm{g}$ wet tissue, with a mean of $179 \mathrm{U} / \mathrm{g}$ wet wt. Their isoenzyme content was predominantly CK-BB (range, 91 to $100 \%$, mean $95 \%$ ). The mean percentage (and range) was $2 \%(0-4 \%)$ for CK-MB $3 \%(0-5 \%)$ for CK-MM. The CK activity of malignant tissue was markedly reduced, with a mean of $51 \mathrm{U} / \mathrm{g}$ wet wt, (ranging from 23 to $120 \mathrm{U} / \mathrm{g}$ ). The isoenzyme patterns were similar to that of normal tissue. The mean percentage (and range) was $87 \%$ $(73-100 \%)$ for CK-BB, $1 \%(0-3 \%)$ for CK-MB, and $12 \%(0-23 \%)$ for CK-MM. The predominant frac- 
CK activities and percentage distribution of CK isoenzymes in normal and tumour tissue from nine patients

\begin{tabular}{|c|c|c|c|c|c|c|c|c|c|c|}
\hline \multicolumn{5}{|c|}{ Normal GI tissue } & \multicolumn{6}{|c|}{ Benign and malignant tumour tissue } \\
\hline Case & $\begin{array}{l}\text { Total } C K \text { activity } \\
(U / g \text { wet } w t)\end{array}$ & $M M \%$ & $M B \%$ & $B B \%$ & $\begin{array}{l}\text { Total CK activity } \\
(U / g \text { wet wt })\end{array}$ & $M M \%$ & $M B \%$ & $B B \%$ & $\begin{array}{l}\text { Tumour } \\
\text { index }\end{array}$ & Differentiation \\
\hline 1 & 111 & 2 & 4 & 94 & 34 & 25 & 2 & 73 & 3 & Mod \\
\hline 2 & 214 & 5 & 1 & 94 & 69 & 0 & 0 & 100 & 3 & Mod \\
\hline 3 & 205 & 0 & 0 & 100 & 120 & 4 & 0 & 96 & 1.7 & Mod \\
\hline 4 & 138 & 4 & 0 & 96 & 45 & 12 & 0 & 88 & 3 & Well \\
\hline 5 & 117 & 1 & 4 & 95 & 25 & 9 & 2 & 89 & $4 \cdot 6$ & Poor \\
\hline 6 & 234 & 3 & 0 & 97 & 23 & 23 & 0 & 77 & 10 & Anaplastic \\
\hline 7 & $157^{*}$ & 5 & 4 & 91 & 53 & 11 & 3 & 86 & 3 & Anaplastic \\
\hline 8 & 258 & 3 & 1 & 96 & 25 & 15 & 1 & 84 & 10 & Mod \\
\hline 9 & 223 & 4 & 0 & 96 & 334 & 0 & 0 & 100 & 0.6 & Adenomatous polyp \\
\hline 10 & 180 & 4 & 1 & 94 & 402 & 20 & 4 & 76 & 0.4 & Adenomatous polyp \\
\hline
\end{tabular}

*Normal and malignant gastric tissue. Mod = Moderate

Tumour index $=\frac{\text { Total CK activity of normal tissue }(\mathrm{U} / \mathrm{g})}{\text { Total CK activity of tumour tissue }(\mathrm{U} / \mathrm{g})}$

tion was still CK-BB, but slightly less than in normal tissue. However, the proportion of CK-MM in the malignant tissue was more than in normal tissue. In contrast, CK activity of two benign tumour tissues, 334 and $402 \mathrm{U} / \mathrm{g}$ wet wt, was markedly more than that of normal tissue. The isoenzyme distribution was very similar to that of malignant tumour tissue. In case 1, a distinctive band that migrated toward the cathode was found (Figure). Serum of this patient showed only CK-MM band. The tumour index (CK activity of normal tissue divided by that of tumour tissue) of malignant tissue ranged from 1.7 to 10 . There was no good correlation between tumour index and differentiation of tumour; however, in two benign tumour tissues, the tumour index was less than 1.

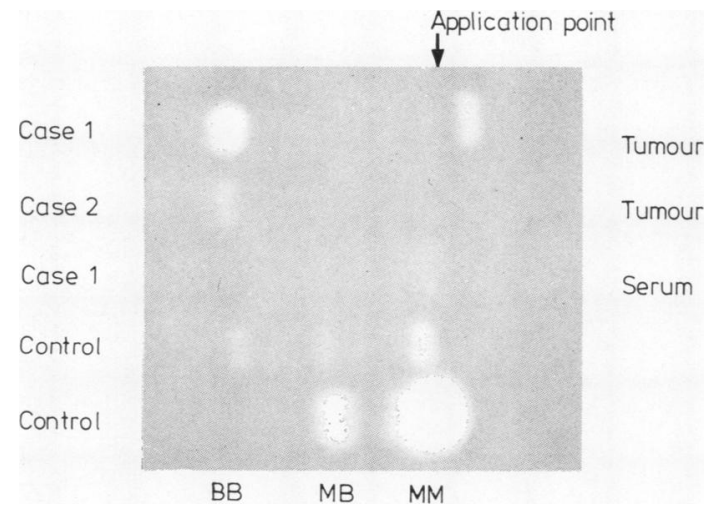

CK electrophoretic patterns of tumour homogenates and patient's serum. Control with three bands: material from Helena Laboratories Control with two bands: serum from one patient with severe polymyositis.

\section{Discussion}

An alteration of isoenzyme pattern was evident between the normal and tumour tissue. In eight patients, the percentage of CK-MM increased when tumour developed; while in two patients (case 2 and 9) CK-BB was enhanced. This small series of patients with neoplasms of GI tract presented findings that are very difficult to assess. The mechanism of this alteration remains entirely speculative. However, this study demonstrated that CK activity per gram wet tissue markedly decreased in malignant tissue, and markedly increased in benign tumour tissue. Obviously, further investigations are necessary to confirm this finding.

In a previous report, ${ }^{6}$ one of eight patients with colon cancer had detectable CK-BB. This patient had diffuse liver metastasis. It is anticipated that a butky tumour mass or an advanced stage is required to release CK-BB into circulation detectable by the routine methods for CK-BB isoenzyme. Therefore, CK-BB may not be a useful tumour marker as advocated by Silverman and associates. ${ }^{7}$ Even with their sensitive method, only $19 \%$ of adenocarcinoma patients with metastasis were found to have circulating CK-BB.

In case 1 , tissue homogenates showed one distinctive band migrated toward the cathode. This may well represent macro-CK as described by Yuu et $a l ;{ }^{8}{ }^{9}$ for the vast majority of the reported cases of macro-CK of cathodal mobility, have been found in patients with malignant tumour. This patient's serum showed no evidence of macro-CK. It is possible also that the CK found in this tumour tissue is a polymer of normal CK, and not a CK-linked immunoglobulin. Similarly migrating bands have been identified as adenylate kinase from tumours ${ }^{10}$ 
or CK from mitochondria. ${ }^{11}$ The exact nature of the band described awaits confirmation by gel filtration or immunofixation.

\section{References}

${ }^{1}$ Tsung SH. Creatine kinase isoenzyme patterns in human tissue obtained at surgery. Clin Chem 1976;22:173-5.

${ }^{2}$ Wreton VJ, Pfleiderer G. Quantitation of creatine kinase isoenzyme in human tissue and sera by an immunologic method. Clin Chim Acta 1975;58:223-32.

${ }^{3}$ Tsung SH, Huang TY, Han D, et al. Creatine kinase and isoenzyme MB activity in serum and skeletal muscle of a patient with dermatomyositis. Clin Chem 1980;26:1812913.

${ }^{4}$ Rosalki SB. An improved procedure for serum phosphokinase determination. J Lab Clin Med 1967;69:696-705.

${ }^{5}$ Yasmineh WG, Hanson NQ. Electrophoresis on cellulose acetate and chromatography on DEAE-Sephadex A-50 compared in the estimation of creatine kinase isoenzyme. Clin Chem 1975;21:381-6.
- Tsung SH. Several conditions causing elevation of CKMB and CK-BB. Am J Clin Pathol 1981;75:711-5.

${ }^{7}$ Silverman LM, Derner GB, Zweig MH, et al. Creatine kinase BB: a new tumor associated marker. Clin Ch'm $1979 ; 25: 1432-5$.

${ }^{8}$ Yuu H, Takagi Y, Senju O. Creatine kinase isoenzyme of high relative molecular mass in serum of a cancer patient. Clin Chem 1978;24:2054-7.

${ }^{9}$ Yuu H, Ishizawa S, Takagi Y, et al. Macro creatine kinase: a study on CK-linked immunoglobulin. Clin Chem $1980 ; 26: 1816-20$.

${ }^{10}$ Turley CP, Gajda AT, McDaniel RC. Interference of adenylate kinase on serum and tissue creatine kinase analyte. Clin Chem 1980;26:994.

${ }^{11}$ Heinz JW, O'Donnell NJ, Lott JA. Apparent mitochondrial creatine kinase in the serum of a patient with metastatic cancer to the liver. Clin Chem 1980;26:190811.

Requests for reprints to: Dr SH Tsung, Department of Pathology, Methodist Hospital of Gary Inc, 600 Grant Street, Gary, Indiana 46402, USA. 